\title{
Interpretasi Multikulturalisme Agama Dan Pendidikan
}

\author{
Desi Erawati \\ IAIN Palangka Raya \\ desi_hana09@yahoo.com
}

\begin{abstract}
Multicultural of meaning can be understand various aspects of life, but more often come to the surface when touched by religious and multicultural education. Pluralist in about have a religion always touted though still much conflict do in the name of religion. In the world of education, just as the discourse of multicultural education, theory, concept, or the like is not on the level of the students have not his actions to realize in life should be. Conceptually speaking, should probably dig the meaning of multicultural local wisdom in the sphere of culture, in order to preserve the local culture and inheritance until not even left forgotten . Huma Betang is a special custom home Dayak tribe, meaning the philosophy contained in it is to appreciate, appreciate the diversity and united together. In this paper highlights how multicultural about have a religion can be understood in the domain and in the domain of education is not merely a matter of discourse but be applicable in understanding the life of nation and state .
\end{abstract}

Keywords: Interpretation, Multikulturalism, Religion, Education

\section{A. Pendahuluan}

Bumi nusantara Indonesia menurut data tahun 2008, wilayah datarannya sekitar $2.000 .000 \mathrm{~km}^{2}$ dan luas wilayah perairannya sekitar $3.000 .000 \mathrm{~km}^{2}$; jumlah pulaunya lebih dari 17.000 dan dihuni lebih dari 230 juta jiwa. Juga kaya dengan nilai sosio budaya yang luhur, sebagai nilai pandangan hidup bangsa. Warisan ini harus dijaga dan dilestarikan oleh segenap bangsa Indonesia, terutama oleh generasi muda. Menjadi tanggung jawab bersama bahwa bagaimana generasi muda mampu melakukannya, mereka harus dididik menjadi warganegara yang cerdas dan baik (smart and good citizen).

Jika perhatian sejenak kita arahkan pada kondisi sosial budaya, maka negara bangsa (nation-state) Indonesia terdiri atas sejumlah besar kelompok-kelompok etnis, budaya, agama dan lain-lain. Hefner mengilustrasikan Indonesia sebagaimana juga Malaysia dan Singapura memiliki warisan dan tantangan pluralisme budaya (cultural pluralism). Kemajemukan masyarakat Indonesia paling tidak dapat dilihat dari dua cirinya yang unik, pertama secara horizontal, ia 
ditandai oleh kenyataan adanya kesatuan-kesatuan sosial berdasarkan perbedaan suku bangsa, agama, adat, serta perbedaan kedaerahan, dan kedua secara vertikal ditandai oleh adanya perbedaan-perbedaan vertikal antara lapisan atas dan lapisan bawah yang cukup tajam. ${ }^{1}$

Bhinneka Tunggal Ika menjadi pondasi terpeliharanya kemajemukan atau keanekeragaman budaya, agama, ras dan etnis yang ada di masyarakat menjadi satu kesatuan yang utuh dalam wilayah Negara Republik Indonesia.

Dalam pandangan Clifford Geertz, Indonesia sedemikian kompleksnya, sehingga sulit melukiskan antonimnya secara persis. Negeri ini bukan hanya multietnis (Jawa, Batak, Bugis, Aceh, Flores, Bali dan seterusnya), melainkan juga menjadi arena pengaruh multimental (India, Cina, Belanda, Portugis, Hindhuisme, Buddhisme, Konfusianisme, Islam, Kristen, Kapitalis, dan seterusnya). $^{2}$

\section{B. Kajian Pustaka}

\section{Pemaknaan Multikultural Dalam Agama dan Pendidikan}

Lawrence A Blum, seorang profesor filsafat di University of Massachusetts di Amherst mendefinisikan multikulturalime meliputi sebuah pemahaman, penghargaan dan penilaian atas budaya seseorang, serta sebuah penghormatan dan keingintahuan tentang budaya etnis orang lain. Ia meliputi sebuah penilaian terhadap budaya-budaya orang lain, bukan dalam arti menyetujui seluruh aspek dari budaya-budaya tersebut, melainkan mencoba melihat bagaimana sebuah budaya yang asli dapat mengekspresikan nilai bagi anggota-anggotanya sendiri. ${ }^{3}$

Pemaknaan multikulturalisme ini juga dipaparkan oleh Bikhu Parekh sebagaimana dikemukakan oleh Saifuddin; Multikulturalisme adalah cara pandang kebudayaan yang diwujudkan secara konkret dalam kehidupan yang nyata. Terminologi multikulturalisme menurut Stavenhagen mengandung dua pengertian. Pertama, ia merupakan realitas sosial dalam masyarakat yang majemuk dan kedua; multikulturalisme berarti keyakinan atau kebijakan yang

${ }^{1}$ Dasim Budimansyah, Pembelajaran Pendidikan Kesadaran Masyarakat Multikultural (Bandung: PT Genesindo, 2008), 2.

${ }^{2}$ Ibid., $3-4$.

${ }^{3}$ Ibid., 4. 
menghargai pluralisme budaya sebagai khasanah kebudayaan yang diakui dan dihormati keberadaannya. Sejalan dengan terminologi di atas, Supardan mengemukakan bahwa kata kunci dalam multikulturalisme ini adalah "perbedaan" dan "penghargaan", dua kata yang selama ini sering dikonfrontasikan.

Multikulturalisme adalah landasan budaya yang terkait dengan pencapaian civility (keadaban), yang amat esensial bagi terwujudnya demokrasi yang berkeadaban, dan keadaban yang demokratis. Negara-negara yang menganut sistem demokrasi, pada umumnya mempunyai kesadaran yang tinggi perihal pentingnnya multkulturalisme untuk membangun torelansi, asimilasi, dan persamaan hak di antara warganegara.

Semua ini merupakan faktor-faktor kunci dalam konsolidasi dan pendalaman demokrasi sehingga negara-bangsa mampu bertahan dan berkelanjutan. Yang tidak kurang pentingnya dalam membangun demokrasi multikultural adalah pengakuan atas kekurangan dan kelemahan yang pernah terjadi dalam upaya-upaya penguatan nation-building.

Terkait dengan pengembangan masyarakat dan demokrasi multikultural di atas, peran penting pendidikan menjadi tak terelakan. Dalam pandangan Azra pembentukan masyarakat multikultural Indonesia yang sehat tidak bisa secara taken for granted atau trial and error. Sebaliknya harus diupayakan secara sistematis, programatis, integrated dan berkesinambungan. Salah satu strategi penting itu adalah pendidikan multikultural yang dapat berlangsung dalam setting pendidikan formal dan informal, langsung atau tidak langsung. Pendidikan multikultural menurut Banks adalah konsep atau ide sebagai suatu rangkaian kepercayaan (set of believe) dan penjelasan yang mengakui dan menilai pentingnya keragaman budaya dan etnis dalam membentuk gaya hidup, pengalaman sosial, identitas pribadi dan kesempatan-kesempatan pendidikan dari individu, kelompok maupun negara. ${ }^{4}$

Terkait dengan paradigma pendidikan yang terkandung dalam pasal 1 (1) yang disebutkan, dalam Pasal 1 (2) UU NO. 20/2003 ditegaskan bahwa :

\footnotetext{
${ }^{4}$ Ibid., 7.
} 
"Pendidikan Nasional adalah pendidikan yang berdasarkan kepada Pancasila dan Undang-Undang Dasar Republik Indonesia Tahun 1945 yang berakar pada nilai-nilai agama, kebudayaan nasional Indonesia dan tanggapan terhadap tututan perubahan zaman."

Ada empat kaidah mendasar yang dapat diidentifikasi dalam kandungan ayat ini, yaitu pendidikan nasional dalam rangka mendukung pembangunan manusia Indonesia yang bemartabat, yaitu bahwa :

1. Landasan filosofis pendidikan nasional adalah Pancasila dengan bertolak dari keyakinan bahwa Pancasila sebagai Dasar Negara, Falsafah Negara, dan Way of life bangsa Indonesia tetap mengandung nilai-nilai dasar yang relevan dengan proses kehidupan dan perkembangan berbangsa dan bernegara, dan memiliki landasan eksistensial yang kokoh baik secara filosofis, yuridis, maupun sosiologis.

2. UUD 1945 sebagai dasar pendidikan nasional mengandung arti bahwa penyelenggaraan pendidikan nasional harus bermuara untuk pembangunan bangsa dan negara. Apabila kita berbicara tentang pendidikan dalam konteks UUD 1945 yang paling diingat dan sering diperbincangkan, walaupun belum diikuti dengan pemaknaan utuh, ialah mencerdaskan kehidupan bangsa.

3. Nilai agama dan budaya menjadi nilai-nilai dasar pendidikan tetapi sekaligus sebagai nilai-nilai yang harus dikembangkan melalui pendidikan dalam konteks pencapaian tujuan utuh pendidikan. Secara historis bangsa Indonesia memang berangkat dari keragaman, dan itulah bangsa yang asli. Oleh karena karakteristik keragaman bangsa Indonesia berbeda dari keragaman bangsa lain, yang dibentuk oleh misalnya kaum imigran seperti Amerika Serikat, maka pendekatan pendidikan yang berasakan multikultur dari Barat akan sejalan dengan esensi "multikultur" di Indonesia.

4. Pendidikan harus tanggap pada perubahan zaman, menegaskan bahwa pendidikan harus berorientasi masa depan dan membangun masyarakat 
Indonesia masa depan yang memiliki daya saing (competitiveness) dan daya keberlanjutan (sustainability) yang kokoh. ${ }^{5}$

Perbedaan latar belakang kebudayaan tersebut menggambarkan bahwa kita tak bisa mengelak keberagaman, karena kita pun tak mampu menolak identitas ganda (multiple identities) yang kita miliki. Identitas ganda itu terbentuk melalui keunikan dan kompleksitas akibat " interseksi” dari ras, etnik kelas sosial, gender, bahasa, agama, orientasi seksual, hingga kemampuan personal. Atas dasar keberagamaan budaya (cultural diversity) itulah, sebagai manusia seutuhnya harus bisa menjalani kehidupan bersama dan membentuk suatu masyarakat yang disebut masyarakat multikultur. Ingatlah bahwa "the diversityof cultures is behind us, before $u$ all around us. The only demand we can make of it .... is that it take froms that each makes a contribution to the utmost generosity of other people", bahwa keragaman budaya ada di belakang kita, di hadapan kita, dan mengelilingi kita. Ungkapan ini mendorong kita untuk segera berpaling dari keyakinan berlebihan atas adanya sebuah masyarakat yang homogen ke arah masyarakat yang heterogen. Lantaran itulah, kini telah muncul konsep-konsep baru yang mendefinisikan sebuah masyarakat baru dengan konsep kebudayaan baru yang terbentuk secara hybrid, mixed, dan diasporic (hybrid society, mixed society, diasporic society.

Konsep-konsep baru tentang masyarakat multikultur juga dapat dikatakan bahwa masyarakat multietnik adalah suatu masyarakat yang struktur penduduknya terdiri dari beragam etnik, dan keragaman itu menjadi sumber keragaman kebudayaan atau subkultur dari masing-masing etnik, sehingga melahirkan suatu masyarakat yang kita sebut masyarakat multikultur. Apa dampaknya? Kita berdiam dalam suatu masyarakat yang "plural" atau majemuk karena kebudayaan yang beraneka ragam. Pertanyaannya, apakah keragaman itu dapat mendorong setiap orang untuk memahami keberadaan multietnik dan multikultur melalui seperangkat ideologi multikulturalisme dan pluralisme ${ }^{6}$

\footnotetext{
${ }^{5}$ Sunaryo Kartadinata, Isu-isu pendidikan: antara harapan dan kenyataan (Bandung: UPI Press, 2010), 56-59.

${ }^{6}$ Alo Liliweri, Prasangka \& konflik: komunikasi lintas budaya masyarakat multikultur (Yogyakarta: PT LKiS Pelangi Aksara, 2005), 61-62.
} 
Sejak awal, ideologi multikulturalisme itu di artikan sebagai suatu bentuk respek yang bersifat mutual dari suatu etnik kepada etnik lain, misalnya memberikan keleluasan agar etnik lain dapat mengekspresikan budaya etniknya, dan ekspresi tersebut merupakan salah satu kontribusi penting bagi pengembangan budaya suatu bangsa.

\section{Metode Penelitian}

Kajian ini menggunakan pendekatan library research, dimana mengumpulkan beberapa referensi yang bertemakan multikulturalisme agama dan pendidikan. Menggunakan analisis dari hal-hal yang bersifat umum kemudian ditarik sebuah kesimpulan khusus, sampai menemukan sebuah analisis atau temuan tentang pemaknaan multikulturalisme agama dan pendidikan.

\section{Hasil Penelitian}

\section{a. Pemaknaan Multikulturalisme Agama dan Pendidikan}

Beberapa hal berikut ini dikemukakan kaitannya dengan multikulturalisme. Pertama, multiulturalisme adalah konsep yang menjelaskan dua perbedaan dengan makna yang saling berkaitan. 1) multikulturalisme sebagai kondisi kemajemukan kebudayaan atau pluralisme budaya dari suatu masyarakat. Kondisi ini diasumsikan dapat membentuk sikap toleransi. 2) multikulturalisme merupakan seperangkat kebijakan pemerintah pusat yang dirancang sedemikian rupa agar seluruh masyarakat dapat memeberi perhatian kepada kebudayaan dari semua kelompok etnik atau suku bangsa. Hal ini beralasan karena, bagaimanapun juga, semua kelompok etnik atau suku dan bangsa telah memberi kontribusi bagi pembentukan dan pembangunan suatu bangsa.

Kedua, di hampir sebagian besar negara, multikulturalisme merupakan konsep sosial yang diintroduksi ke dalam pemerintahan agar pemerintah dapat menjadikannya sebagai kebijakan pemerintahan.

Ketiga, jika dikaitkan dengan pendidikan multikultural (multicultural education), multikulturalisme merupakan strategi pendidikan yang memanfaatkan keragaman latar belakang kebudayaan dari para peserta didik sebagai salah satu kekuatan untuk membentuk sikap multikultural. Strategi ini sangat bermanfaat; sekurang-kurangnya dari sekolah sebagai lembaga pendidikan, dapat terbentuk 
pemahaman bersama atas konsep kebudayaan, perbedaan budaya, keseimbangan, dan demokrasi dalam arti luas.

Keempat, multikulturalisme sebagai sebuah ideologi dapat dikatakan sebagai gagasan bertukar pengetahuan dan keyakinan yang dilakukan melalui pertukaran kebudayaan atau perilaku budaya setiap hari. Artinya, daripada kita hidup dalam "tempurung" kebudayaan sendiri, maka sebaiknya kita mempelajari kebudayaan orang lain. Ini sama dengan kita belajar tentang multikultural. Melalui ideologi multikulturalisme itulah, kita semua diajak untuk menerima standar umum kebudayaan yang dapat membimbing, kehidupan kita dalam sebuah masyarakat yang majemuk. ${ }^{7}$

Beberapa definisi tentang multikultur, maka dapat dilihat secara umum, penerimaan atas dua paham multikulturalisme dan pluralisme mengandung dua makna penting dari multikulturalisme. Pertama, kaum multikulturalis yakin bahwa penyadaran individu atau kelompok itu sangat ditentukan oleh informasi dan pengetahuan, padahal informasi dan pengetahuan (termasuk informasi dan pengetahuan budaya) umumnya tidak netral.

Kedua, multikulturalisme merupakan sebuah ideologi yang menolak klaim formal tentang definisi budaya dan kebudayaan yang sudah terstruktur dalam sebutan kebudayaan nasional. Struktur berpikir seperti ini ditolak; apalagi sejak globalisasi melanda dunia, konsep kebudayaan nasional tidak dapat diterima begitu saja. Mengapa tidak? Jika seseorang tetap bertahan pada "melebihlebihkan" kebudayaan nasional tanpa menyadari bahwa dia sedang hidup dalam dunia global, maka dia mempunyai peluang yang sangat kecil untuk mengubah masa depannya. Multikulturalisme yang terjadi di Eropa, secara de facto, merupakan aliansi pemikiran yang dibentuk oleh pemikiran etnik-etnik dengan penganut paham nasionalis yang pada sebuah gilirannya menganjurkan terbentuknya sebuah kebudayaan makro.

Berbagai makna multikultur, maka perlu kiranya menelaah multikultur dalam ranah pendidikan sebagaimana yang diungkapkan oleh James A. Banks dikenal sebagai perintis pendidikan multikultur. Menurut Banks, bagian terpenting

${ }^{7}$ Ibid., 68-69. 
dari pendidikan mahasiswa adalah mengajarkan kepada mereka "bagaimana cara mereka berpikir" dan bukan mengajarkan "apa yang mereka pikirkan". Kata dia, mahasiswa harus diajarkan untuk berpikir bagi memahami semua tipe pengetahuan, sehingga mereka bisa lebih aktif dalam perdebatan tentang konstruksi pengetahuan dan pertentangan interprestasi keilmuan.

Menurut Banks, mahasiswa harus diinstruksikan agar mereka hidup dalam kemampuan untuk mencipta, memiliki kreasi melalui interprestasi, tidak saja tentang sejarah masa lalu, melainkan yang lebih penting adalah bagaimana sejarah itu terjadi. Para mahasiswa harus belajar mengidentifikasi diri dan posisi mereka, kepentingan dan minat mereka, filsafat hidup mereka yang ideal, serta asumsiasumsi teoretis yang mereka bangun. Ringkasnya, para mahasiswa harus menjadi pemikir yang kritis dengan latar belakang pengetahuan dan keterampilan, ditambah dengan komitmen. Hal ini sangat dibutuhkan agar mereka berpartisipasi dalam tindakan demokrasi. Dengan dasar ini, mahasiswa dapat menolong bangsanya keluar dari perbedaan penghayatan dan penglihatan antara idealisme dengan realitas.

Dalam tulisannya berjudul The Canon Debat, Knowledge Construction, and Multicultural Education, Banks mengidentifikasi tiga kelompok terpelajar yang berpartisipasi dalam perdebatan pengetahuan. Pertama, kaum tradisionalis Barat seperti kelompok pluralisme budaya yang dirintis Kallen. Kelompok ini percaya bahwa kebudayaan dominan adalah kebudayaan yang berasal dari peradaban Barat; peradaban Barat dibutuhkan sebagai perintis perkembangan ilmu pengetahuan dan teknologi sekarang.

Kedua, kelompok kedua adalah mereka yang menafikan kebudayaan Barat secara berlebihan. Katanya, kita harus hati-hati menilai peradaban Barat, yang mengutamakan pembentukan pengetahuan dari segelintir orang yang menjadi pintar lalu menafikan eksistensi kelompok budaya lain. Ternyata, sejarah mencatat bahwa peran kehadiran kelompok budaya lain itu sangat penting dalam perkembangan sebuah bangsa.

Ketiga, kelompok ketiga disebut multikulturalis yang percaya bahwa pendidikan harus direformasikan agar dapat memberikan sedikit perhatian dan 
pengalaman kepada orang kulit berwarna kaum perempuan. Dengan demikian, perlu kesetaraan sistem dan kurikulum pendidikan yang mendukung kesetaraan pengetahuan orang-orang kulit berwarna (etnik dan kelompok etnik serta minoritas) dan kaum perempuan yang selama ini secara historis terabaikan. ${ }^{8}$

Beberapa pendapat tersebut, terindikasi bahwa multikultur adalah sebuah keniscayaan dan keharusan menghargai dan menyadari dari berbagai aspek kehidupan baik agama, sosial, budaya, ekonomi, hukum dan pendidikan yang berbeda.

Sikap multikultur akan terkontaminasi manakala adanya timbul prasangka atau prejudice. Ada tiga strategi yang dapat dirancang untuk mengurangi prasangka sosial antaretnik atau antarras :

Pertama, mengatasi masalah komunikasi. Program ini sebagai langkah pertama untuk meningkatkan kemampuan peserta mengatasi masalah komunikasi antaretnik. Dasar pemikiran dari program ini demikian; kerap kali sebagian besar prasangka sosial antaretnik tumbuh (ditumbuhkan dengan sengaja atau bertumbuh secara alamiah) oleh kesalahpahaman antaretnik itu dimungkinkan oleh kecendrungan seseorang yang membuat kesalahan asumsi terhadap informasi tentang etnik dan ras, terutama stereotip antaretnik. Contoh paling sering adalah stereotip antaretnik dalam komunikasi verbal dan nonverbal. Kedua, cara pertama rupanya hanya sedikit menolong memperbaiki kemiskinan komunikasi antaretnik dan tidak selalu mengatasi prasangka. Komunikasi yang baik, meski sederhana, ingin membuktikan pada sesama etnik melalui kenyataan yang terkesan menghargai dua pihak.

Ketiga, kunci terakhir mengurangi prasangka adalah berkomunikasi dalam tindakan yang ramah tamah terhadap sesama. Misalnya, toleran terhadap perbedaan etnik atau ras, khususnya ketika kita mendekati isu-isu moral. Kunci ini mengintegrasikan sistem bagi kesamaan nilai, sehingga kita dapat memahami nilai-nilai transendental.

Kita memerlukan tiga unsur itu, atau kombinasi dari ketiganya, dalam proses memahami bagaimana prasangka menggarisbawahi disposisi setiap orang

${ }^{8}$ Ibid, h.71-78 
terhadap etnik lain. Pemaknaan multikultur sebenarnya bukan hanya dalam tataran dunia keagamaan saja tetapi merambah pada semua aspek kehidupan salah satunya adalah di bidang pendidikan.

Dalam perjalanannya selama empat dasawarsa lebih, pendidikan telah memberikan sumbangan yang luar biasa besarnya dalam proses transformasi masyarakat Indonesia, dari tradisionalis ke modernis, dari agraris ke indrustrialis, bahkan ke gerbang warga bangsa yang mempunyai kesadaran higt-tech. Inilah proses panjang yang oleh Karl Deutsch atau Daniel Lerner disebut mobilisasi sosial. Dalam konteks komunitas Islam, tidak terlalu berlebihan jika Nurcholis Madjid melihat kenyataan ini sebagai "ledakan intelektual".

Poin penting yang dapat diambil dari pernyataan singkat di atas adalah demikian kuatnya kaitan antara pendidikan dan transformasi masyarakat Indonesia, paling tidak dari sudut pandang meningkatnya kalangan terdidik dan/atau berbudaya metropolitan.

Dalam konteks ini bisa dipahami, mengapa sampai beberapa waktu lalu pemerintah masih membanggakan keharmonisan keagamaan masyarakat Indonesia kepada dunia luar. Dan dewasa ini masyarakat meratapi betapa rapuhnya dasar-dasar keharmonisan kehidupan keagamaan kita. Atas dasar itu, dapat mengajukan pertanyaan, mengapa keterkaitan antara pendidikan dengan penghargaan pluralisme agama tidak sekuat keterkaitan antara pendidikan dengan transformasi sosial masyarakat?

Jawaban pintas dari pertanyaan di atas, adalah kenyataan bahwa pendidikan telah direduksi menjadi sekedar pengajaran. Di sini yang lebih menonjol adalah hal-hal yang bersifat kognitif, penguasaan terhadap subjek akademik, dan bukan pengembangan watak anak didik tentang bagaimana bersikap terhadap realitas lingkungan yang secara keagamaan bersifat pluralistik.

Pada masa sebelum Orde Baru, kehadiran pendidikan agama di sekolahsekolah umum, baik yang negeri atau swasta, bersifat sukarela. Ini, antara lain, karena kejengkelan terhadap ateisme komunis di satu pihak, dan keinginan publik agar nilai-nilai agama juga disosialisasikan sejak dini melalui lembaga-lembaga 
pendidikan, sejak awal Orde Baru pendidikan agama menjadi mata pelajaran yang wajib diberikan.

Meskipun demikian, peraturan itu tidak cukup compulsive, seakan-akan tidak mempunyai konsekuensi hukum yang tegas, sehingga pendidikan agama benar-benar menjadi mata pelajaran yang diberikan di sekolah. Sering kali karena pertimbangan-pertimbangan teologis/politis tertentu, lembaga-lembaga pendidikan swasta merasa tidak begitu compulsive untuk memberikan pendidikan agama kepada anak-didik sesuai dengan agama yang dianutnya. Inilah kemudian yang ikut memicu ketegangan antara hubungan antarumat beragama. Baru pada akhir dasawarsa 1989, sebuah undang-undang pendidikan baru digulirkan. Di situ, secara eksplisit diakui peran pengajaran agama pada semua tingkat pendidikan. Ditegaskan pula tentang kualifikasi guru agama, yaitu bahwa guru agama harus menganut agama yang diajarkan dan yang dianut oleh siswa yang mengikuti pelajaran tersebut. ${ }^{9}$

Kendatipun pengaturan legal seperti ini telah disahkan, tetap saja protes dan penolakan dari kalangan agama tertentu terus bermunculan-sesuatu yang menunjukkan watak eksklusif, partikular, dan primordial pemeluk agama. Dengan itu, bagian-bagian tertentu dari undang-undang pendidikan dimentahkan oleh peraturan pemerintah yang membuat undang-undang bisa dijalankan. Bahkan, salah satu Peraturan Pemerintah (PP No.29/1990) secara eksplisit menyatakan bahwa sekolah-sekolah menengah dengan warna agama tertentu tidak diharuskan memberikan pelajaran agama yang berbeda dengan agama yang dianutnya. ${ }^{10}$

Ini semua menunjukkan, di bidang pendidikan agama pun toleransi masyarakat beragama tidak cukup tebal. Untungnya, kita memiliki negara yang ketika itu relatif kuat walaupun bukan tanpa biaya tinggi bagi aspek kehidupan sosial-kemasyarakatan dan politik yang lain. Ia melalui berbagai peraturan ideologis dan politis, berperan sebagai satu-satunya buffer zone yang dapat menahan intoleransi yang disebabkan oleh padangan-pandangan teologis/politis tertentu, sehingga fenomena seperti dipaparkan di atas tidak berkembang ke arah

${ }^{9}$ Undang-Undang Republik Indonesia Nomor 2 Tahun 1989 Tentang Sistem Pendidikan Nasional, n.d.

${ }^{10}$ PP No.29/1990 Harus Ditinjau Kembali”, Panji Masyarakat, 1991, 71. 
hal-hal yang bersifat destruktif. Dalam struktur yang tidak terlalu ketat, masyarakat agama yang heterogen itu diikat oleh sebuah wordview yang dijadikan kesepakatan bersama, yaitu sila “ Ketuhanan Yang Maha Esa”. Dalam rumusan yang mendatangkan konsekuensi-konsekuensi legal, mereka dibatasi oleh kebijakan tentang SARA. Departemen Agama, sejak masa Alamsyah Ratu Perwiranegara, menggulirkan langkah-langkah yang disebut " trilogi kerukunan umat beragama"- kerukunan interen umat beragama, kerukunan antarumat beragama dan kerukunan antarumat beragama dengan pemerintah. ${ }^{11}$

Pendidikan pluralis-multikultural adalah proses penyadaran yang berwawasan pluralis (secara agama) dan sekaligus berwawasan multikultural (secara budaya). Pendidikan pluralis-multikultural harus dilihat sebagai bagian dari usaha komprehensif menghindari, mencegah, dan menanggulangi konflik bernuansa etnis dan agama di masa mendatang. Tidaklah cukup hanya membentuk wadah-wadah institusional yang melibatkan seluruh komponen umat beragama seperti Sekretariat Bersama Majelis-majelis Agama, sementara program strategi dan kongkretnya tidak ada sama sekali. Pendidikan pluralis-multikultural ini harus menjadi proyek bersama yang berjangka panjang.

Toleransi merupakan sikap warga negara yang aktif, bukan sikap spontan. La tolerance est une position civique active, et on pas une attitude spontanee, tulis Fernando Savater. Artinya, sikap toleran tidak akan tertanam dengan sendirinya, tanpa ada usaha sadar menginternalisasikannya. Torelansi pluralisme, dan multikulturalisme harus dididikkan, tidak cukup berhenti pada wacana. Keputusan majelis ulama, keputusan konsili, kesempatan sidang dewan gereja-gereja sedunia, dan kesepakatan hasil pertemuan tokoh agama yang menganjurkan toleransi dan kerja sama tidak akan cukup efektif apabila hanya berhenti di kertas, tanpa dukungan pendidikan dalam arti yang luas.

Ada pepatah Arab "Kamu adalah musuh dari apa yang kaum tidak ketahui". Peserta didik yang mempelajari beragam agama dan budaya akan lebih mudah bersikap toleran daripada mereka yang hanya belajar pada satu agama

\footnotetext{
${ }^{11}$ Bahtiar. Effendy, Masyarakat Agama Dan Pluralisme Keagamaan: Perbincangan Mengenai Islam, Masyarakat Madani, Dan Etos Kewirausahaan (Yogyakarta: Galang Press, 2001), 45-50.
} 
yang dianutnya saja. Pangkal mengentalnya prasangka adalah karena pendidikan (agama) selama ini bersikap eksklusif dan sarat indoktrinasi.

Keberhasilan pendidikan agama lebih sering dilihat dari seberapa banyak hapalan kitab suci dan pengetahuan tata cara ritual. Teks-teks agama yang diajarkan hanya yang memperkuat iman dan solidaritas seiman, apalagi pengajarannya bersifat tekstual dan simbolik, tidak kontekstual dan subtantifistik. Padahal, teks-teks agama cukup sarat dengan pluralisme dan karena itu harus dididikkan. Misalnya, "Dan sebagai tanda kebesaran Tuhan, bahwa Dia menciptakan langit dan bumi juga pluralitas bahasa dan warna kulit manusia." (Al- Qur'an:20:22). “Tuhan tawarkan bagi manusia banyak jalan, andaikan Tuhan tidak melakukan demikian; Tuhan ingin menguji di tengah pluralitas itu". (AlQur'an:5:48). Dan seterusnya.

Wawasan pluralis-multikultural dalam pendidikan agama merupakan bekal penting agar kalangan terpelajar dan masyarakat luas menghargai perbedaan, menghormati secara tulus, komunikatif, terbuka, dan tidak saling curiga, selain untuk meningkatkan iman dan takwa. Pendidikan pluralis bukanlah mengajarkan anak didik untuk menjalankan agama dengan seenaknya sendiri, tanpa tanggung jawab dan ketulusan, tetapi justru mengajarkan untuk taat beragama, tanpa menghilangkan identitas keagamaan masing-masing. Wajah agama yang ditampilkan pendidikan pluralis adalah agama yang moderat dan ramah.

Dr. Eka Dharmaputra, pakar teologi dari Kristen Protestan mengatakan, salah satu sumbangan terpenting teologi pluralis adalah asumsi dasarnya bahwa semua agama dapat menyumbangan sesuatu, bukannya satu dapat menyelesaikan semua. Makin mutlak klaim seseorang makin menderitalah manusia. Melalui pendidikan pluralis, agama-agama memberikan kontribusi bagi pembangunan bangsa menuju masyarakat multikultural. Pendidikan agama merupakan pilar penyangga kerukunan umat beragama dan kerukunan umat beragama merupakan pilar kerukunan bangsa. Pendidikan agama merupakan penyangga kerukunan umat beragama dan kerukunan umat beragama merupakan pilar kerukunan bangsa. 
Pendidikan pluralis-multikultural tidak sekedar untuk memahami keragaman agama dan budaya, tetapi juga memahami nilai-nilai bersama yang bisa di-sharing sebagai dasar hidup bersama.

Tujuan pendidikan pluralis-multikultural adalah untuk memahami simpati, apresiasi, dan empati terhadap penganut agama dan budaya yang berbeda. Lebih lanjut lagi penganut agama dan budaya yang berbeda dapat belajar untuk melawan ketidaktoleran (i'intorelable) seperti inkuisisi (pengadilan negara atas sahtidaknya teologi atau ideologi), perang agama dan diskriminasi. ${ }^{12}$

Oleh karena itu, untuk membentuk pendidikan yang mampu menghasilkan manusia yang memiliki kesadaran pluralis-multikultural, diperlukan rekonstruksi pendidikan sosial keagamaan dalam pendidikan agama. Maksudnya, kalau selama ini praktik lapangan pendidikan agama masih menekankan sisi keselamatan yang dimiliki dan didambakan oleh orang lain di luar diri dan kelompoknya sendiri maka pendidikan agama perlu direkontruksi kembali, agar lebih menekankan proses edukasi sosial yang tidak semata-mata individual dan memperkenalkan konsep social-contract. Dengan demikian, pada diri peserta didik, tertanam suatu keyakinan bahwa kita semua sejak semula memang berbeda-beda dalam banyak hal, lebih-lebih dalam bidang akidah, iman, kredo. Namun, demi menjaga keharmonisan, keselamatan, dan kepentingan kehidupan bersama, mau tidak mau kita harus rela menjalin kerja sama dalam bentuk kontrak sosial antara semua kelompok warga masyarakat. Dengan reorientasi ini, diharapkan akan terjadi perubahan proses dan mekanisme pembelajaran menuju ke arah teriptanya pemahaman dan kesadaran pluralis-multikultural kepada anak didik. ${ }^{13}$

Menurut Frans Magnis Suseno, pendidikan pluralisme adalah suatu pendidikan yang mengandaikan kita untuk membuka visi pada cakrawala yang lebih luas, mampu melintas batas kelompok etnis atau tradisi budaya dan agama kita sehingga kita mampu melihat "kemanusiaan" sebagai sebuah keluarga yang memiliki perbedaan maupun kesamaan cita-cita. Inilah pendidikan akan nilai-nilai dasar kemanusiaan untuk perdamaian, kemerdekaan dan solidaritas.

${ }^{12}$ Muhammad Ali, Teologi Pluralis-Multikultural (Jakarta : Buku Kompas, 2003), 99-103.

${ }^{13}$ Ngainun Naim and Achmad Sauqi, Pendidikan multikultural: konsep dan aplikasi (Ar-Ruzz Media, 2008). 
Ainurrafiq Dawam menjelaskan bahwa pendidikan multikultur adalah proses pengembangan seluruh potensi manusia yang menghargai pluralitas dan heterogenitasnya sebagai konsekuensi keragaman budaya, etnis, suku, dan aliran (agama). Pengertian pendidikan multikultural yang demikian, tentu mempunyai implikasi yang sangat luas dalam pendidikan. Karena pendidikan itu sendiri secara umum dipahami sebagai proses tanpa akhir atau proses sepanjang hayat. Dengan demikian, pendidikan multikultural menghendaki penghormatan dan penghargaan setinggi-tingginya terhadap harkat dan martabat manusia dari manapun dia datangnya dan berbudaya apapun dia. Harapannya adalah terciptanya kedamaian yang sejati, keamanaan yang tidak dihantui kecemasan, dan kebahagiaan tanpa rekayasa. ${ }^{14}$ Pendidikan semacam ini dapat diposisikan sebagai bagian dari upaya komprehensif untuk mencegah dan menanggulangi konflik etnis agama, radikalisme agama, separatisme, dan integrasi bangsa. Sedangkan nilai dasar dari konsep pendidikan ini adalah toleransi.

Tujuan pendidikan pluralis-multikultural bukan untuk membuat suatu kesamaan pandangan, apalagi keseragaman, karena ini adalah sesuatu yang absurd dan agak mengkhianati tradisi suatu agama. Yang dicari adalah mendapatkan titik-titik pertemuan yang dimungkinkan secara teologis oleh masing-masing agama. Setiap agama mempunyai sisi ideal secara filosofis dan teologis, dan inilah yang dibanggakan penganut agama, serta yang akan menajdikan mereka tetap bertahan, jika mereka mulai mencari dasar rasional atas keimanan mereka. Akan tetapi, agama justru mempunyai sisi riil, yaitu suatu agama menyejarah dengan keagungan atau kesalahan-kesalahan sejarah yang bisa dinilai dari sudut pandang sebagai suatu yang memalukan. Oleh karena itu, suatu dialog dalam pendidikan pluralis-multikultural harus selalu mengandalkan kerendahan hati untuk membandingkan konsep-konsep ideal yang dimiliki agama lain yang hendak dibandingkan.

Adapun metode yang dapat diterapkan dalam pendidikan pluralismultiultural adalah dengan menggunakan model komunikatif dengan menjadikan aspek perbedaan sebagai titik tekan. Metode dialog ini sangat efektif, apalagi

${ }^{14}$ Ainurrafiq Dawan, Emoh Sekolah (Yogyakarta: Inspeal Ahimsa Karya Press, 2003), 100. 
dalam proses belajar mengajar yang sifatnya kajian perbandingan agama dan budaya. Sebab, dengan dialog memungkinkan setiap komunitas yang notabenenya memiliki latar belakang berbeda agama dapat mengemukakan pendapatnya secara argumentatif. Dalam proses inilah diharapkan nantinya memungkinkan adanya sikap lending and borrowing serta saling mengenal antar tradisi dari setiap agama yang dipeluk oleh masing-masing peserta didik. Sehingga bentuk-bentuk truth claim dan salvation claim dapat diminimalkan, bahkan kalau mungkin dapat dibuang jauh-jauh.

Metode dialog ini pada akhirnya akan dapat memuaskan semua pihak sebab metodenya telah mensyaratkan setiap pemeluk agama untuk bersikap terbuka (open minded). Di samping juga bersikap objektif dan subjektif sekaligus. Objektif maksudnya sadar bahwa membicarakan banyak iman secara fair tanpa harus mempertanyakan mengenai benar-salahnya suatu agama. Subjektif maksudnya pengajaran seperti itu sifatnya hanya untuk mengantarkan setiap peserta didik memahami dan merasakan sejauh mana keimanan tentang suatu agama dapat dirasakan oleh setiap orang yang mempercayainya. ${ }^{15}$

Hampir semua manusia menyadari bahwa keragaman dan perbedaan merupakan sebuah keniscayaan yang harus diterima dan dihadapi, walaupun terkadang sikap yang kurang tepat terhadap agama yang ada sering menjadi sebuah konflik, jika bukannya permusuhan dan peperangan. Berhenti pada tampakan keragaman dan perbedaan tertentu membuka peluang untuk terjadi ragam konflik kemanusiaan. Oleh karenanya, manusia dituntut untuk mencari titik-titik tertentu yang memungkinkan adanya titik temu atau paling tidak kebersamaan, sehingga terbuka peluang untuk tumbuhnya sikap toleran dalam menyikapi pluralitas.

Media yang paling tepat untuk menggambarkan dan menerangkan hakikat kemanusiaan tersebut dalam agama, sebab agama tidak hanya berbicara dalam ranah materi manusia, tetapi sampai pada tingkatan yang terinti dari manusia itu, yaitu kemanusiaannya.

${ }^{15}$ Syamsul Ma'arif, Pendidikan Pluralisme Di Indonesia (Jogjakarta: Logung Pustaka, 2005), 9697. 
Persoalan kemanusiaan harus dilihat sebagai persoalan seluruh agama. Kekerasan dan tragedi kemanusiaan yang terjadi atas nama agama telah mencoreng wajah agama yang sebenarnya ramah dan penuh kedamaian. Orang yang beragama semestinya orang yang mampu memberikan keselamatan bagi orang lain, bukan mampu memberi ancaman bagi sesamanya. Karenanya tragedi kemanusiaan, seperti dianalisis T.H. Sumartana seharusnya menjadi suatu peringatan bahwa kesadaran agama tidak dapat lagi dijabarkan atau diekspresikan secara parsial saja. ${ }^{16}$ Dengan kata lain, agama-agama harus menyadari bahwa tugasnya menyelamatkan umat manusia tidak dapat lagi dilakukan secara sendirisendiri.

Sebagai agama dengan ajarannya yang bersifat universal, Islam sangat menekankan nilai-nilai kemanusiaan. Kemanusiaan adalah satu. Manusia bukan saja berasal dari suatu kehendak yang menciptakan, yakni kehendak Tuhan.

Sejalan dengan itu Islam juga menegaskan universalisasi prinsip-prinsip moral. Moral Islam ini memperkuat hubungan antar-anggota masyarakat, mempersatukan perasaan yang merupakan dasar kebajikan universal dan mempersatukan kaidah-kaidah yang memaksa yang sangat perlu bagi kehidupan kolektif.

Tugas menjaga agama menjadikan Islam melarang pemaksaan dalam agama maupun pemurtadan. Dengan menjaga nyawa, Islam melarang pembunuhan tanpa hak. Q.S An-nissa ayat 92, yang artinya : dan tidak layak bagi seorang mukmin membunuh seorang mukmin (yang lain), kecuali karena tersalah (tidak sengaja).

Dan menghukum sebagai pembunuhan massal bagi seorang pembunuh walaupun yang terbunuh hanya satu orang. Q.S Al- Maidah ayat 32, yang artinya: Oleh karena itu Kami tetapkan (suatu hukum) bagi Bani Israil, bahwa: Barangsiapa yang membunuh seorang manusia, bukan karena orang itu (membunuh) orang lain atau bukan karena membuat kerusakan di muka bumi, Maka seakan-akan Dia telah membunuh manusia seluruhnya.

\footnotetext{
${ }^{16}$ T.H. Sumartana, Agama Dan Ancaman Kemanusiaan, Dalam Kelompok Studi Proklamasi (Ed) Agama Dan Kekerasan (Jakarta: Esensia, 1985), $166 .$.
} 


\section{b. Multikulturalisme dalam Filosofi Huma Betang}

Makna kenakeragaman dalam kehidupan manusia khususnya dalam budaya suku Dayak telah berkembang dengan makna filosofi Huma Betangnya. Huma secara semantik berarti rumah dan betang berarti panjang/besar. Huma betang berarti rumah panjang atau rumah besar. Konstruksi bangunan huma betang memungkinkan dihuni 100-200 anggota keluarga atau 10-40 kepala keluarga. Huma betang dengan struktur panggung yang dihuni banyak kepala keluarga dirancang oleh para aktornya sesuai dengan kondisi alam di Kalimantan Tengah. Munculnya huma betang dilatarbelakangi oleh beberapa faktor. Pertama, (menurut Ahim S. Rusan) budaya kayau mengayau/potong kepala (headhunting) yang dilakukan oleh suku Dayak Iban terhadap suku Dayak lain. Kedua, (Ahmad Syar'i) semangat persatuan dan kebersamaan dari suku-suku Dayak lain serta hasrat untuk hidup bersama, saling membantu satu dengan lain. Ketiga, melindungi eksistensi kelompok dari serangan atau ancaman suku Dayak Iban. Keempat, membangun solidaritas persaudaraan, rasa sepenanggungan dan kebersamaan dalam menghadapi setiap ancaman dan gangguan yang dating dari pihak luar. ${ }^{17}$

Penghuni huma betang jumlahnya bisa mencapai puluhan orang dengan tingkat keanekaragaman budaya, sub-etnik dan agama. Interaksi sosial komunitas huma betang melahirkan satu tatanan budaya bersama, disebut budaya betang, yaitu budaya masyarakat suku Dayak yang hidup damai meskipun memiliki keyakinan berbeda. ${ }^{18}$

Penyang ketun hinjei simpei, patarung ketun hamba tamburak, taketun belum panju-panjung, tatau sanang urah ngalawan, kilau bulan matan andau tanggeran lewu maderah danum.

Terjemahannya :

" Bersatulah kamu dengan seluruh kekuatan, dengan satu padumu kamu akan hidup bahagia, sejahtera seperti bulan, matahari dan bintang di langit sebagai contoh dan teladan."

\footnotetext{
${ }^{17}$ Muhammad, Dkk, Falsafah Hidup Budaya (Huma Betang Dalam Membangun Kerukunan Hidup Umat Beragama Di Kota Palangka Raya, Kalimantan Tengah) (Yogyakarta: Aditya Media Publishing, 2010), 49-52.

${ }^{18}$ Ibid., 50-51.
} 
Amun ketun penyang pangangkarak simpei, te ketun akan gandang tatah lewu mendereh danum, amun patarung bahkuhas tambaruk, akan gandang biwih rundang hampamantai tambun.

Terjemahannya :

" Kalau terjadi perpecahan, engkau akan diejek dan dihina oleh bangsa lain, agar dunia ini damai sejahtera, hidup di dunia dan sempurna di dunia lain, maka berpeganglah kepada pedoman hidup yaitu agama." 19

Filosofi budaya kearifan lokal tersebut bisa dikembangkan dalam dunia pendidikan, dengan mengembangkannya melalui kurikulum sebagai mata pelajaran muatan lokal setempat, tujuannya adalah agar generasi muda atau peserta didik akan selalu tetap menjaga dan melestarikan budaya bangsa. Konsep hidup bergotong royong selalu dibudayakan, menghargai perbedaan, menyadari keanekaragaman budaya, ras dan agama, dan berniat bersama-sama untuk menjalin tujuan bersama "berbeda-beda tetapi tetap satu jua”.

\section{E. Kesimpulan}

Indonesia kaya akan keanekaragaman budaya, agama, bahasa dan segala keunikannya dengan keadaaan pulau yang terpisah-pisah tetapi tetap dalam kesatuan republik Indonesia. Keragaman inilah tentunya harus tetap dipertahankan bukan menjadi perlawanan atau pertikaian. Paham multikultural adalah salah satu cara untuk dapat tetap bertahan dan tetap aman, karena disana walaupun bangsa Indonesia beragam tetapi tetap saling memahami, menyadari segala perbedaan yang ada, karena disatukan oleh niatan yang sama bersatu damai dan aman, tentram sentosa.

Multikulturalisme dalam dikembangkan melalui jenjang sekolah dengan mengembangkan kurikulum muatan lokal seperti khas budaya Kalimantan Tengah terkenal dengan filosofi Huma Betang, secara substansi bermakna penghargaan atas perbedaan itu adalah alami dan hidup gotong royong menjadi point yang tak terlupakan.

${ }^{19}$ Ibid., 57. 


\section{Daftar Pustaka}

Ainurrafiq Dawan. Emoh Sekolah. Yogyakarta: Inspeal Ahimsa Karya Press, 2003.

Budimansyah, Dasim. Pembelajaran Pendidikan Kesadaran Masyarakat Multikultural. Bandung: PT Genesindo, 2008.

Effendy, Bahtiar. Masyarakat Agama Dan Pluralisme Keagamaan: Perbincangan Mengenai Islam, Masyarakat Madani, Dan Etos Kewirausahaan. Yogyakarta: Galang Press, 2001.

Kartadinata, Sunaryo. Isu-isu pendidikan: antara harapan dan kenyataan. Bandung: UPI Press, 2010.

Liliweri, Alo. Prasangka \& konflik: komunikasi lintas budaya masyarakat multikultur. Yogyakarta: PT LKiS Pelangi Aksara, 2005.

Ma'arif, Syamsul. Pendidikan Pluralisme Di Indonesia. Jogjakarta: Logung Pustaka, 2005.

Muhammad Ali. Teologi Pluralis-Multikultural. Jakarta : Buku Kompas, 2003.

Muhammad, Dkk. Falsafah Hidup Budaya (Huma Betang Dalam Membangun Kerukunan Hidup Umat Beragama Di Kota Palangka Raya, Kalimantan Tengah). Yogyakarta: Aditya Media Publishing, 2010.

Naim, Ngainun, and Achmad Sauqi. Pendidikan multikultural: konsep dan aplikasi. Ar-Ruzz Media, 2008.

PP No.29/1990 Harus Ditinjau Kembali”, Panji Masyarakat, 1991.

T.H. Sumartana. Agama Dan Ancaman Kemanusiaan, Dalam Kelompok Studi Proklamasi (Ed) Agama Dan Kekerasan. Jakarta: Esensia, 1985.

Undang-Undang Republik Indonesia Nomor 2 Tahun 1989 Tentang Sistem Pendidikan Nasional, n.d. 